\title{
The Effects of Lending Interest Rates, Inflation Rates, and Investment on Economic Growth of South East Asian Countries
}

\author{
${ }^{1}$ Rika Yuliastanti ${ }^{*}{ }^{2}$ Ali Farhan, ${ }^{3}$ Sri Rahayu, ${ }^{4}$ Roy Sumaryono, ${ }^{5}$ Nindya Kartika Kumayati
}

Lecturer STIE Mahardhika

\begin{abstract}
This study aims to determine the effect of lending interest rates, inflation and the investment rate on economic growth in South East Asiancountries over the past seventeen years (2000-2017). This study uses a quantitative method with multiple linear regression analysis, the sample used is data from the World Bank about lending interest rates, inflation, and investment in South East Asian countries that are members of the World Bank during the period 2000-2017. From the results of multiple linear regression analysis it was found that both the lending interest rate, inflation and investment rate variables had a positive effect but unsignificant on the economic growth of South East Asian countries during 2000-2017.
\end{abstract}

Keywords: Economic Growth, Inflation, Lending Interest Rate.

\section{Background}

Economic growth is a measuring variable that shows the economic condition of a country. Economic growth is also a goal for each country to advance itself through economic prosperity in order to prosper its people, such as reducing unemployment, increasing productivity portrayed by Gross Domestic Product, adequate food and surplus trade balance.

In many studies in the economic issue, there come a debate about economic growth, whether economic growth is influenced by the rate of inflation or vice versa, the rate of inflation is influenced by economic growth (Maknun, 1995). Mallik and Chowdhurry (2001) argue that ahighly rapid on economic growth triggers inflation, while Ahluwaliyah (2013) says that inflation has a positive impact on economic growth, in casethe inflation been controlled, different findings are delivered by Daniel (2018) who found that inflation had a negative effect on economic growth. Unlike the case with Ahluwaliyah (2013), Maknun (1995), and Mallik and Chowdhurry (2001) which consider inflation as a variable that affects the level of economic growth, Parakkasi (2016) actually argues that lending interest rates and investment are factors that influence the economic growth.

Based on some of the results of the above research, this research will elaborate on the effect of inflation, investment and lending interest rates on economic growth in ASEAN countries during the period 20072017.

\section{1. Research Question}

Based on the background, the formulation of the problem raised is:

1. Does the Lending interest Rate have a significant effect on economic growth?

2. Does inflation have a significant effect on economic growth?

3. Does investment have a significant effect on economic growth?

\section{2. Thinking Framework}

Based on the background and the research question above, the hypothesis of this study is:

Hypothesis

$\mathrm{H}_{0} \quad=$ There is an unsignificant effect of Lending Interest Rates, Inflation and Investment Rates on Economic Growth 
$\mathrm{H}_{1} \quad=$ There is a significant effect of Lending Interest Rates on Economic Growth

$\mathrm{H}_{2} \quad=$ There is a significant effect of Inflation on Economic Growth

$\mathrm{H}_{3} \quad=$ There is a significant effect of Investment Rates on Economic Growth

Picture 1: Framework for the Effect of Lending interest Rates, Inflation, Investment on Economic Growth

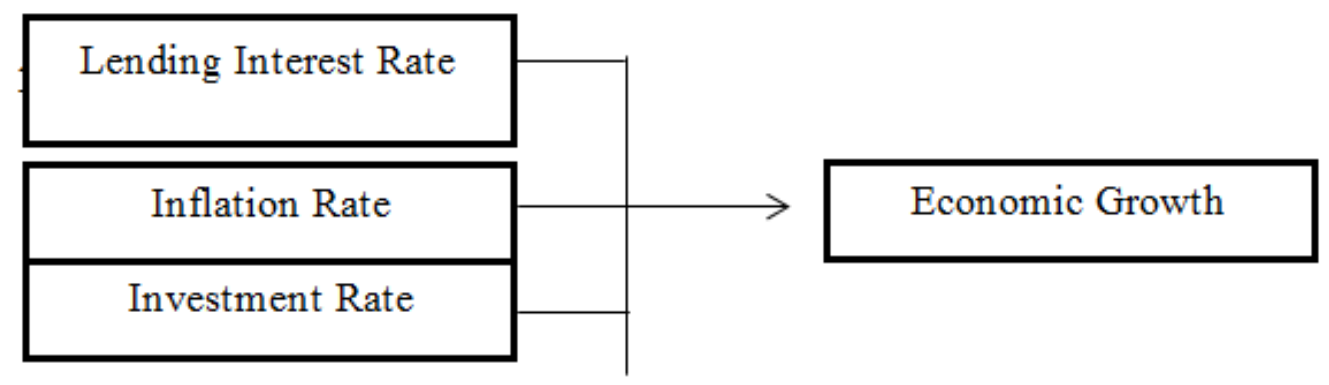

\section{Literature Review}

\section{a. Economic growth}

Economic growth can be explained as an increase in economic production capacity which is manifested as an increase in national income (Gross Domestic Product) (Daniel, 2018; Lubis, 2014). Increasing the volume of production in real terms, both goods and services is often not the same as the increase in production potential, so that means economic growth is considered slower than its potential (Sukirno, 1994), such inequality can occur due to consumer purchasing power over the production potential possessed by an economy is not in line with the economy's ability to produce goods and services.

The low purchasing power in the economy can be caused by continuous and general price increases, which by Prakkasi (2016) are considered to be the cause of the decline in economic growth.

\section{b. Inflation}

As an economic phenomenon, inflation is a theme that is widely discussed. Keynes said that inflation emerged as a result of consumption activities that surpassed supply availability in the economy (Towunusa et al, 2016). Nopirini (2000) and Towunusa et al (2016) describe inflation as a continuous increase in prices and occur in all products. For Keynes inflation has a negative impact on economic growth, while Friedmann states that inflation will affect the economy in the long run if the inflation is triggered by the circulation of money that is greater than real production (Lubis, 2014). Gokal and Hanif (2004) state that inflation has a negative effect on economic growth and the same is also stated by Miloš and Švigir (2017) in his study of economic growth in Italy and Austria, that inflation has a negative effect on economic growth. Maknun (1995) expressed a different opinion, based on the Philips Curve as real inflation and increasing economic growth, because in an inflationary economy the people tend to produce to get profits, increased production activities can reduce the unemployment rate in an economy.

\section{c. Lending interest Rate}

Interest is defined as rewards given for using borrowed money (Martina and Prastiwi, 2014). The interest rate given is influenced by the amount of money borrowed (Martina and Prastiwi, 2014). Fahmi and Hadi (2010) add that the interest rate is also determined by the length of time the loan, changes in the value of the future and the inflation rate. Firdaus and Ariyanti (2009) stated that the interest rate is also based on the level of profit expected by the bank to the credit provided. The lending interest rate for Towunusa et al (2016) did not have a significant effect on economic growth, inversely proportional to the findings of Prakkasi in the same year (2016) that credit interest rates negatively affected economic growth, in line with Prakkasi (2016), Mutinda ( 2014) and Mudaki et al (2014) in their research in Kenya and Akinwale (2018) on their findings in Nigeria, suggesting that lending interest rates have a negative effect on economic growth.

\section{d. Investment rate}

Investment is defined by Prakkasi (2016) as an increase in the stock of physical capital, through property development, manufacturing of machinery, construction of factories, infrastructure or stock of goods, in 
addition to adding physical assets can also be interpreted as increasing human capital, which is a characteristic typical investment. Discussion on economic theory also talks about the relationship between investment and economic growth, Solow (1956) as stated by Li (1998) stating that investment will increase labor productivity which dynamically productivity will encourage the economic growth. This opinion is justified by Roux and Moyo (2018) in his research stating that investment in the long term will increase economic growth, as well as the findings of Awer and Sampath (1999) which state the same thing.

\section{Research Methods}

\section{a. Type of Research}

Research that aims to test hypotheses and the relationship between two or more variables are grouped as quantitative research (Sugiyono; 2004; 2007; Anshori and Iswati, 2009), because this article examines the effect of lending interest rates and inflation rates on economic growth in South East Asian coutries then this article can be considered quantitative research. The variables tested in this study are dependent variables; Economic growth while independent variables; Lending interest Rates and Inflation Rates.

\section{b. Population and Samples}

The population in this study is data on the economic conditions of the countries that were linked to the World Bank during the period 1961-2017. While the sample chosen is the economic condition of South East Asiancountries represented by the level of GDP (Gross Domestic Product), inflation rate, and lending interest rates during the period 1997 to 2017, the selection of samples is carried out according to predetermined criteria, the criteria being the sample in this study is South East Asiancountries that are registered as members of the World Bank.

Data Type

The data used is secondary data downloaded from the official website of the World Bank.

Data collection technique

The data collection technique used in this study is literature.

Data analysis

\section{Multiple Regression Analysis}

Multiple regression analysis is the regression of a response variable on more than one explanatory variable (Saefuddin, Notodiputro et al, 2009). This multiple regression analysis can be done if the number of independent variables is minimal 2. In this study there are three independent vaiables, namely; 1) The Interest Rate of Loans, 2) Inflation Rate, 3) the investment rate.

\section{Analysis and Discussion}

In the linear regression test requires the fulfillment of the requirements of classical assumptions that must be fulfilled, so that the resulting prediction model will be BLUE (Best Linear Unbiased Estimation). The classic assumption in multiple linear regression are: normality, homoskedasticity, and non multicollinearity tests

\section{Normality test}

Table 1: Normality Test of the Kolmogorof-Smirnov Test Data

\begin{tabular}{|ll|r|}
\hline \multicolumn{2}{|c|}{ One-Sample Kolmogorow-Smirmon Test } \\
\hline$N$ & $\begin{array}{c}\text { Unstandardiz } \\
\text { edResidual }\end{array}$ \\
Normal Parameters= & Mean & 162 \\
& Std. Deviation & .0000000 \\
Most Extreme Differences & 2.68757194 \\
& Absolute & .054 \\
& Positive & .054 \\
Kolmogorov-Smirnov $Z$ & Negative & -.053 \\
Asymp. Sig. (2-tailed) & & .682 \\
\hline
\end{tabular}

a. Test distribution is Normal. 
Classical Assumption Testing Normality Test using the Kolmogorov-Smirnor one-sample test of 0.740 is greater than the Sig> 0.05 value. It can be concluded that the data in the model are normally distributed.

\section{Multicollinearity Test}

\section{Table 2: Multicollinearity Test}

\begin{tabular}{|c|c|c|c|c|c|c|c|c|}
\hline \multicolumn{9}{|c|}{ Coefficients ${ }^{3}$} \\
\hline \multirow[b]{2}{*}{ Madel } & & \multicolumn{2}{|c|}{ Unstandardized Coefficients } & \multirow{2}{*}{$\begin{array}{c}\begin{array}{c}\text { Standardized } \\
\text { Coefficients }\end{array} \\
\text { Beta }\end{array}$} & \multirow[b]{2}{*}{$t$} & \multirow[b]{2}{*}{ Sig. } & \multicolumn{2}{|c|}{ Collinearity Statistics } \\
\hline & & $B$ & Std. Error & & & & Tolerance & VIF \\
\hline \multirow[t]{4}{*}{1} & (Constant) & 2.110 & .430 & & 4.903 & .000 & & \\
\hline & Lending Rate & .235 & .038 & .493 & 6.253 & .000 & .596 & 1.676 \\
\hline & Inflation Rate & .087 & .030 & .225 & 2.898 & .004 & .617 & 1.621 \\
\hline & Investmen Rate & .115 & .039 & .183 & 2.927 & .004 & .950 & 1.053 \\
\hline
\end{tabular}

a. Dependent Variable: GDP

Based on the results of multicollinearity tests that have been done, the results show that for the three independent variables there were no symptoms of multicollinearity. This is indicated by the number table variance internal factor that is not more than 10 and the number in the tolerance table is more than 0.1

\section{Heterocedasticity test}

\section{Table 3: Heterocedasticity test}

\begin{tabular}{|c|c|c|c|c|c|c|c|c|}
\hline \multicolumn{9}{|c|}{ Coefficients $^{\mathrm{s}}$} \\
\hline \multirow[b]{2}{*}{ Mad } & & \multicolumn{2}{|c|}{ Unstandardized Coefficients } & \multirow{2}{*}{$\begin{array}{c}\begin{array}{c}\text { Standardized } \\
\text { Coefficients }\end{array} \\
\text { Beta }\end{array}$} & \multirow[b]{2}{*}{$t$} & \multirow[b]{2}{*}{ Siq. } & \multicolumn{2}{|c|}{ Collinearity Statistics } \\
\hline & & B & Std. Error & & & & Tolerance & $\mathrm{V} / \mathrm{F}$ \\
\hline \multirow[t]{4}{*}{1} & (Constant) & 1.648 & .257 & & 6.415 & .000 & & \\
\hline & Lending Rate & .029 & .022 & .132 & 1.299 & .196 & .596 & 1.676 \\
\hline & Inflation Rate & -.001 & .018 & -.006 & -.063 & .950 & .617 & 1.621 \\
\hline & Investmen Rate & .047 & .023 & .163 & 2.026 & .044 & .950 & 1.053 \\
\hline
\end{tabular}

a. Dependent Variable: Abs_RES

Based on the Sig table the heteroscedasticity test shows that the sig value> 0.05 means that there are no symptoms of heteroscedasticity in the data.

\section{Regression Test}

\section{Table 4: T test}

\section{Coefficients ${ }^{3}$}

\begin{tabular}{|c|c|c|c|c|c|c|}
\hline \multirow{2}{*}{\multicolumn{2}{|c|}{ Madel }} & \multicolumn{2}{|c|}{ Unstandardized Coefficients } & \multirow{2}{*}{$\begin{array}{c}\begin{array}{c}\text { Standardized } \\
\text { Coefficients }\end{array} \\
\text { Beta }\end{array}$} & \multirow[b]{2}{*}{$\mathrm{t}$} & \multirow[b]{2}{*}{ Siq. } \\
\hline & & $\mathrm{B}$ & Std. Error & & & \\
\hline \multirow[t]{4}{*}{1} & (Constant) & 2.110 & .430 & & 4.903 & .000 \\
\hline & Lending Rate & .235 & .038 & .493 & 6.253 & .000 \\
\hline & Inflation Rate & .087 & .030 & .225 & 2.898 & .004 \\
\hline & Investmen Rate & .115 & .039 & .183 & 2.927 & .004 \\
\hline
\end{tabular}

a. Dependent Variable: GDP

$\mathrm{Y}=2.110+0.236 \mathrm{X} 1+0.087 \mathrm{X} 2+0.115 \mathrm{X} 3+\mathrm{e}$

Where:

$\mathrm{Y}=$ Gross Gross Variable

A $\quad=$ Constant

$\mathrm{B}=$ Regression Coefficient

$\mathrm{X} 1=$ Lending interest Rate
$\mathrm{X} 2$ = Inflation Rate

X3 = Investment rate

$\mathrm{e}=$ Variables that are not examined 
Based on the results of the $\mathrm{T}$ test on multiple regression analysis shows that the variable lending interest rate, inflation rate, and investment rate shows that partially each variable have anunsignificant effect on economic growth. These results can be seen in the Sig. table On each variable whose value is less than 0.05. This is different from the findings of previous studies which stated that inflation, investment and lending interest rates significantly influence economic growth.

\section{a. Lending Interest Rate}

Although it has an unsignificant effect on economic growth, Lending Interest Rate shows a positive influence on economic growth, it can be seen from the coefficient in the regression equation for $\mathrm{X}_{1}$ value of 0.236, which means that the Lending Interest Rate variable has a positive effect of $2.36 \%$ on Economic growth, while $97.63 \%$ is influenced by other variables besides Lending Interest Rate. This finding is inversely proportional to the research conducted by Prakkasi (2016), Mutinda (2014), Mudaki (2014), and Akinwale (2014) which states that Lending Interest Rate has a positive effect on Economic Growth

\section{b. Inflation Rate}

Similar to the Lending Interest Rate, which has a positive influence on economic growth, the inflation rate is also not significant. Positive coefficient of 0.087 has unsignificant effect on economic growth. This finding is different from what was stated by Gokal and Hanif (2004) and Miloš and Švigir (2017) who argue that inflation has a negative effect on economic growth.

\section{c. Investment Rate}

It does not differ from the Lending Interest Rate and Inflation Rate, which has a positive influence on economic growth, but the same thing happens in the Investment Rate variable. Positive coefficient of 0.115 indicates that the investment rate has a positive and unsignificant effect on economic growth. This is in line with Roux and Moyo (2018) and Solow (1956) in Li (1998) which states that the Investment Rate has a positive effect on Economic Growth.

\section{Table 5: Test $\mathrm{F}$}

ANOVA ${ }^{b}$

\begin{tabular}{|ll|r|r|r|r|r|}
\hline \multicolumn{1}{|c|}{} & \multicolumn{1}{c|}{$\begin{array}{c}\text { Sum of } \\
\text { Squares }\end{array}$} & \multicolumn{1}{c|}{ df } & Mean Square & \multicolumn{1}{c|}{ F } & Siq. \\
\hline 1 & Regression & 819.806 & 3 & 273.269 & 37.128 & $.000=$ \\
& Residual & 1162.910 & 158 & 7.360 & & \\
& Total & 1982.716 & 161 & & & \\
\hline
\end{tabular}

a. Predictors: (Constant), Investmen Rate, Inflation Rate, Lending Rate

b. Dependent Variable: GDP

The ANOVA test shows that simultaneously the three variables have a significant influence on economic growth, these results can be seen in the table Sig. Which has a significance value of less than 0.05 , which in the F test table stated that a variable has significance when the Sig. $<0.05$

\section{Closing}

\section{a. Conclusion}

1. Lending Interest Rate partially has anunsignificant positive effect on economic growth.

2. Inflation Rate partially has a positive and anunsignificant effect on economic growth.

3. The investment rate partially has anunsignificant positive effect on economic growth 4. Lending Interest Rate, Inflation Rate, and Investment Rate simultaneously have a positive effect that is anunsignificant for economic growth.

\section{b. Suggestion}

1. No reason has been found for why the results show are unsignificant, further research is expected to analyze. 


\section{c. Implication}

The result of this discusscion is, to encourage the economic growth the stakeholder may pay attention on lending interest rate, investment rate, and also inflation rate since of those variables give a postitive effect on economic growth even the effect is unsignificant.

\section{Reference}

[1.] Anwer, Muhammad S. Sampath, R.K. 1999. Investment and Economic Growth. Clolorado State University.

[2.] Daniel, Prima Audia. 2018. "Analisis Pengaruh Inflasi Terhadap Laju Pertumbuha Ekonomi Di Kota Jambi.” EKONOMIS: Jurnal of Economics and Business Vol.2 No.1 March 2018.

[3.] Hanif, Subrina. Gokal, Vikesh. 2004. Relationship Between Inflationand Economic Growth. Reserve Bank of Fiji. Fiji.

[4.] Li, Dajin. 1998. Investment Rate and Economic Growth in the Long Run: Empirical Tests of Endogenous Growth Modeis. Carleton University.

[5.] Lubis, Ismail Fahmi. 2014. "Analisis Hubungan Antara Inflasi dan Pertumbuhan Ekonomi: Kasus Indonesia”. QE Journal. Vol.03 - No.01 - 41.

[6.] Maknun, Mappaujung. 1995. "Hubungan Kausalitas Antara Inflasi dan Pertumbuhan Ekonomi di Beberapa Negara ASEAN”. Jurnal Ekonomi dan Bisnis Indonesia Vol 10 No.1 Tahun 1995.

[7.] Mallik, Girijasankar. Chowdhury, Anis. 2001. Inflation and Economic Growth: EvidenceFrom Four South Asiann Countries.Asian-Pacific Development JournalVol. 8, No. 1, June 2001.

[8.] Martina, Emy. Prastiwi, Dwi. 2014. "Pengaruh Inflasi, Gross Domestic Product, Suku Bunga Kredit, Loan To Asset Ratio, Dan Kualitas Aktiva Produktif Terhadap Non Performing Loan”. Jurnal Ilmu Manajemen. Volume 2 Nomor 2 April 2014.

[9.] Mutinda, Daniel Musyoka. 2014. The Effect of Lending Interest on Economic Growth in Kenya. Thesis. University of Nairobi.

[10.] Prakkasi, Idris. 2016. “Analisis Dampak Suku Bunga Terhadap Pertumbuhan Sektor RiilDan Sektor Investasi Dalam Perspektif Syariah Di KotaMakassar.” Jurnal Penelitian Humano. Vol. 7 No. 2 November 2016.

[11.] Roux, Pierre le. Moyo, Clement. 2019. Interest rate reforms and economic growth: the savings and investment channel. Munich Personal RePEc Archive no; 85297.

[12.] Saefuddin Asep, Notodiputro Khairil Anwar, Alamudi Aam, Sadik Kusman. 2009. Statistika Dasar. Jakarta: PT Grasindo

[13.] Sambiri, Mudaki John. Otieno, Ojala Daphen. Marice, Mwangi. 2014. Lending Rates and its impact on Economic Growth in Kenya. Journal of Economics and Sustainable Development ISSN 2222-1700 (Paper) ISSN 2222-2855 (Online). Vol.5, No.19, 2014.

[14.] S.O, Akinwale. 2018. Bank Lending Rate and Economic Growth: Evidence from Nigeria. International Journal of Academic Research in Economic and Management Sciences. ISSN: 2226-3624.

[15.] Sugiyono, A. (2007). "Metode penelitian kuantitatif, kualitatif dan R\&D." Bandung: Alfabeta.

[16.] Švigir , Mario. Miloš, Josipa. 2017. Relationship between Inflation and Economic Growth; Comparative Experience of Italy and Austria. Journal FIP Volume 5. $\quad$ Number 2. 2017.

[17.] Tuwonusa ,Wenry.Rotinsulu, Tri Oldi. Mandeij, Dennij.2016. “Analisis Pengaruh SukuBunga Kredit Dan Inflasi Pada Kredit Yang Disalurkan Oleh Bank Umum Dampaknya Terhadap Pertumbuhan Ekonomi Study Kasus Provinsi Sulawesi Utara 2009-2013."Jurnal Berkala Ilmiah Efisiensi. Volume 16 No. 03 .2016. 